\title{
Gesinsmoorde - waar pas die kerk in?
}

\author{
J.T. de Jongh van Arkel \\ Departement Praktiese Teologie \\ Universiteit van Suid-Afrika \\ PRETORIA
}

\begin{abstract}
Taking the final report of the HSRC's exploratory study on family murder as a point of departure, the involvement of clergy and church regarding the phenomenon of family murder is discussed in this article. After highlighting some of the findings of the exploratory study, specific problematic aspects are addressed. The inplications of the Christian message of hope to people in the simation of hopelessness, murder and suicide implicit in the phenomenon of family murder, are also evaluated. Likewise, the problematic relationship between the consequences of the gospel and the requirements for mental health is also touched upon. This relationship is looked at from the perspective of certain aspects of the empirical research done in this field. Furthernore, the possible supporive role of the church is stressed: this 'ecology of care' and the church's message of hope ough to be functional in the situation of hopelessiess accompanying family murder. In conclusion, certain preventative actions, in which the church may be instrumental, are pointed out.
\end{abstract}

Die vraag oor die rol van die kerk by gesinsmoorde roep noodwendig kritiese vrae oor die effektiwiteit van die kerk se boodskap en pastorale bediening op. Dit impliseer ook die kerk se betrokkenheid by die wel en wee van mense asook by hulle psigiese welsyn. Die tragiese gebeure laat verskeie vrae van teologiese, algemeen godsdienstige, Christelik-etiese en pastorale ard ontstaan - vrae wat aan die kerk en Christelike teologie gerig word. In hierdie artikel sal sommige van hierdie vrae ter sprake wees - terwyl die rol van die kerk by gesinsmoorde ook aandag sal kry.

\section{DIE RGN-VERSLAG EN DIE KERK}

Predikante en die kerk is verskeie kere ter sprake in die finale verslag van die uitgebreide empiriese navorsing oor gesinsmoord wat tussen 1988 en 1991 deur die Raad vir Geesteswetenskaplike Navorsing (RGN) onderneem is (Olivier et al., 1991a, 1991b, 1991c). Die empiriese deel van die navorsing het drie bene gehad: 'n poskaartnavraag, 'n uitgebreide vraelys en 'n kwalitatiewe deel waarin gevallestudies van outentieke gesinsmoorde gedoen is. Predikante het deel gevorm van die groep professionele persone in hulpverleningsprofessies wat gevra is om terugvoer te gee (deur middel van die poskaart en uitgebreide vraelys) oor hulle betrokkenheid by gesinsmoorde. In die kwalitatiewe deel van die navorsing is by elke geval indringend navraag 
gedoen oor kerklike betrokkenheid en geloofsoortuigings. Dié verslag bied dus 'n redelike beeld van die direkte betrokkenheid van predikante en die kerk by gesinsmoorde.

'n Poskaart is aanvanklik aan 'n gestratifiseerde monster van 12855 professionele persone uitgestuur. Hierdie groep het bestaan uit sielkundiges, predikante, maatskaplike werkers, mediese praktisyns en skoolhoofde. Hulle is, onder andere, gevra hoeveel gevalle van gesinsmoord hulle gedurende die afgelope 5 en 10 jaar, onderskeidelik, hanteer het. Die predikante was uiteindelik die swakste groep respondente: slegs 6,75 persent van hulle (243 uit 'n groep van 3600 predikante uit sewentien kerklike denominasies) het die poskaarte teruggestuur (Olivier et al., 1991a:223). (Ook het slegs een predikant die uitgebreide vraelys, wat later uitgestuur is, voltooi.)

Volgens die respons op die poskaarte, was 14,3 persent van die predikante pastoraa betrokke by gesinsmoorde. Dit is effens hoër as mediese praktisyns ( 11,9 persent $)$ maar heelwat laer as maatskaplike werkers (33,9 persent) en sielkundiges $(24,4$ persent). Anders uitgedruk, toon dit dat predikante uit die aard van hul bediening by $10,4 \%$ van die gemelde gevalle van gesinsmoord betrokke was (Olivier et al., 1991a:227).

Die respondente wat aangedui het dat hulle reeds by sulke gevalle betrokke was en gewillig was om verder saam te werk, het 'n uitgebreide vraelys ontvang om in te vul. Uit die antwoorde op hierdie uitgebreide vraelyste het geblyk dat min respondente (naas die een predikant, was maatskaplike werkers, sielkundiges en mediese praktisyns respondente) spesifieke kennis gehad het van die kerklike betrokkenheid van die gesinsmoordgevalle, waarby hulle betrokke was. Hulle het wel aangedui dat $71,43 \%$ van die betrokkenes uit Protestantse denominasies, $14,29 \%$ van pentakostalistiese denominasies en slegs een geval uit die Rooms-Katolieke kerk afkomstig was. Twee van die gevalle se kerkverband was heeltemaal onbekend (Olivier et al., 1991a:253) Dit was nie moontlik om te bepaal hoe aktief hierdie mense by hulle kerke betrokke was nie.

Elf indringende gevallestudies van outentieke gesinsmoorde is ook onderneem (ses wit, drie swart en een bruin). Kerklike betrokkenheid in hierdie groep het gewissel van geen betrokkenheid tot besonder aktief. Dit is interessant dat slegs drie van die gesinsmoordenaars 'n aktiewe rol in die kerk gespeel het, terwyl nog twee matig tot min by hulle kerke betrokke was. Die drie besonder aktiewe persone was lidmate van die Presbiteriaanse Kerk, Ou Apostoliese Kerk en Sewende Dag Adventiste Kerk. Die lidmaat van die Gereformeerde Kerk was net matig betrokke (sy vrou was voor hulle troue lid van 'n pentakostalistiese groep en sy het kort voor die insident weer soontoe begin gaan). Een van die gesinsmoordenaars was vroeer 'n diaken in die Nederduitse 
Gereformeerde Kerk maar het later net by geleentheid die kerk besoek. By drie van die gesinne was daar ook aanduidings dat man en vrou uit verskillende kerklike tradisies afkomstig was (Olivier et al., 1991a:127-129).

Gevolgtrekkings uit en verklarings van hierdie gegewens moet versigtig gemaak word. Die verslag kom wel self met enkele verklarings. As 'n moontlike rede vir die lae betrokkenheid van die predikante word gemeld dat predikante moontlik nie veel met patologiese gevalle werk nie maar slegs as verwysingsagente vir hulle dien (Olivier $e t$ al., 1991a:224). Hierdie verklaring hou egter nie rekening met die bevindings wat in die VSA gemaak is en moontlik ook waar kan wees vir die situasie in Suid-Afrika nie. In die VSA is gevind dat mense met ernstige psigiatriese probleme net so veel na predikante gaan as na ander professies in die veld van geestesgesondheid (Larson et al., 1988:1068; vgl. ook Winett et al., 1979:318,320,322). Selfs indien die RGN se bewering waar was, sou 'n mens kon verwag dat die predikante tog sou geweet het van die gevalle wat deur hulle verwys is vir gespesialiseerde hulp en ten spyte daarvan nog op 'n gesinsmoord uitgeloop het. Normaalweg is predikante betrokke by mense uit hulle eie gemeente en ken hulle daardie mense tot 'n redelike mate.

Wat wel waar is, is dat mense betrokke by gesinsmoorde blykbaar as 'n reel nie predikante in hulle vertroue neem nie. Oor die redes hiervoor kan net gespekuleer word. In die verslag word genoem dat hulle moontlik skuldig kan voel oor wat hulle beplan en dat mense wat gesinsmoord pleeg, moontlik nie baie aktief by 'n kerk betrokke is nie (Olivier et al., 1991a:228).

Die verslag (Olivier et al., 1991a:312-313) kom nogtans by die aanbevelings weer terug op die belangrike rol wat predikante (en dus die kerk) in voorkoming kan speel. Dit wil voorkom of die navorsers oortuig is dat kerklike hulpverlening waardevol kan wees en 'n meer prominente rol behoort te speel. Daarvoor sal dit nodig wees om die vertroue van lidmate te wen, die vermoë te ontwikkel om gevaartekens van hoërisikogedrag te kan identifiseer, kennis en sensitiwiteit te hê vir verwysing, nie die noodsaak van die rehabilitering van mense met hoërisikogedrag te onderskat nie en, indien die predikant nie daarvoor geskool is nie, die nodige verwysing te doen, om die konsepte van sonde en skuld met hoop en vergiffenis te balanseer, die belangrikheid om pastorale werk op grondvlak (huisbesoek) te besef en die oop-deurbeleid vir hulp maksimaal te benut.

\section{DIE OMVANG VAN KERKILKE BETROKKENHEID}

Wanneer kerklike betrokkenheid ter sprake is, gaan dit nie net om die pastoraat aan mense wat in ' $n$ krisis is nie. Die tema van lewe en verlossing as 'n gawe van God aan 
die mens is sentraal in die verkondiging van die evangelie. Die ketk is 'n leweskeppende konteks. Mense se lewens word geraak en beïnvloed deur preke, gesprekke en tussenmenslike kontak. Daar word aanvaar dat 'n kerk (gemeente) 'n bepaalde 'kultuur', lewenstyl en onderling aanvaarbare morele gedrag skep waarin die volheid van lewe en die skepping van lewensruimte vir mekaar dominant is.

\subsection{Die Christelike boodskap en moraliteit}

Die veronderstelling is dat aspekte van die verkondigde boodskap sigbaar gestalte behoort te kry terwyl ander weer met die meer persoonlike oortuigings en lewensbenadering verweef is. Dit wil voorkom of laasgenoemde aspek (die persoonlike) besig is om meer omvatttend te word, terwyl die area van konsensusgedrag/oortuiging drasties vernou. Die eenheid van moraal onder Christene is meer en meer aan die verdwyn (Kuitert, 1981:241).

Ons leef in die tyd van die mondige mens, die mens wat nie alleen sy eie besluite neem nie maar ook aanspraak maak op outonomie in sy/haar persoonlike (moreel-godsdienstige) lewe. In die moderne gemeenskappe is die openbare wêreld sonder uitsondering 'n pluralistiese morele wêreld. Die tyd is selfs verby toe pluralisme 'n aanduiding van die verskille tussen Gereformeerdes, Metodiste en Rooms-Katolieke was.

Every minister in our society, every lay leader, every religious engaged person works and acts in a pluralistic culture and social situation. This means that they function in a socicty marked by a plethora of different religious, cultural, and moral views. In a pluralistic socicty assumptions about these matters are not always widely shared (Browning, 1983:13).

Die insidensie van gesinsmoorde in Suid-Afrika beklemtoon die feit dat die moraal wat die kerk verkondig oor moord, selfmoord en die verantwoordelikheid teenoor ander, dikwels nie in die praktyk neerslag vind nie. Helder en duidelik word die woord van Exodus 20: 13; "Jy mag nie moord pleeg nie" elke Sondag van kansels gehoor. Die radikalisering van hierdie gebod in Matteus 5:21 en 22 laat die aksent op woede en negatiewe gevoelens as motief vir die moord val. Die moontlikheid is egter sterk dat daar eerder reddingsfantasieë by die gesinsmoord ter sprake is. Die gesinsmoordenaar 'verlos' die ander lede van die gesin op dieselfde wyse as wat hy homself deur sy eie selfmoord verlos uit 'n hopelose situasie (De Jongh van Arkel, 1985:141). Indien hierdie teorie waar is, sou dit ook kan wees dat die gelowige gesinsmoordenaar rasionaliseer dat die gebod op moord nie op hom van toepassing is nie: sy daad is 'n 'goeie' daad en nie 'n slegte daad nie.

Die moderne gesekulariseerde mens se outonomie oor die lewe word weerspieël in die daad van gesinsmoord. In die keuse om die gesin uit te wis en daarna selfmoord te 
pleeg word iets van hierdie 'reg' wat die mens homself toe-eien, konkreet. Gesinsmoord is 'n keuse vir die dood bo die lewe waarin die wil van God wat die lewe gee en neem, oorstem word. Dit kan 'n keuse wees waarin God se wil nie ter sprake is nie.

Daar is egter ook nog 'n ander moontlikheid. Die keuse vir die dood mag dui op 'n verdraaide (geloofs)oortuiging dat hierdie lewe minderwaardig is en die lewe saam met God die enigste ware lewe is. Die kerk sal weer moet nadink oor die moontlike romantisering van die lewe na die dood in haar boodskappe (De Jongh van Arkel, 1985:142-143). Wat is die implikasie van 1 Korintiers $15: 44$ en 45 asook Filippense 1:21 en $23^{1}$ vir die mens wat oortuig is dat daar geen hoop en geen hulp in hierdie lewe meer oor is nie? Is die dood ' $n$ aanvaarbare alternatief as keuse, 'n moreel regverdigbare keuse vir sommige Christene? Word die lewe genoegsaam as appèl en roeping voorgehou of is dit maar die 'voorfase' vir die ewige (eintlike) lewe, die lewe na die dood?

\subsection{Die evangelie en geestesgesondheid}

Gesinsmoorde dui op 'n probleem op die vlak van geestesgesondheid. Geestesgesondheid is ' $n$ aanduiding van algemene welsyn. Die reikwydte van die evangelie van Jesus Christus sluit ook aspekte van menslike welsyn in. Die besorgheid van die Christelike kerke oor die geestesgesondheid van alle mense is 'n spesifieke manifestasie van haar groter verbondenheid tot die welsyn van mense in die aangesig van uitgebreide lyding (Anderson, 1989:123). Naas die aspek van kerk en geestesgesondheid moet die probleem van die relasie tussen persoonlike geloof (of godsdiens) en geestesgesondheid ook in die kollig geplaas word.

Die verhouding tussen 'godsdienstigheid' en geestesgesondheid is reeds 'n ou tema. Om die saak te opper, skep reeds verskeie probleme: Wat is die definisie van geestesgesondheid? Is daardie definisie teologies aanvaarbaar (vgl. Tjeltveit, 1989:134-136)? Watter godsdiens is hier ter sprake? Hoe word godsdienstigheid geoperasionaliseer? Geen wonder dat navorsers (Sanua, 1977:177,180; Crawford, Handal \& Wiener, 1989:16; Ellison et al., 1989:101) vind dat die empiriese navorsing oor hierdie verhouding soms teenstrydige resultate gelewer het nie. Die rede hiervoor lê, onder andere, in die uiteenlopende konsepte van godsdienstigheid en geestesgesondheid wat gebruik word.

I ... om te lewe, is vir my Christus, en om te sterwe, is vir my wins. Ek is in 'n tweestryd: ek verlang daarna om heen te gaan en met Christus te wecs, want dit is verreweg die beste." 
Die komplekse aard van die verhouding tussen godsdienstigheid en geestesgesondheid moet deeglik in ag geneem word. 'n Liniêre kousale verband tussen godsdienstige betrokkenheid en geestesgesondheid is nie so eenvoudig aan te toon nie. Daar is altyd die moontlikheid dat die verhouding ook andersom verstaan kan word, naamlik dat 'n verhoogde deelname in godsdienstige samekomste en geïntensifiseerde godsdienstige ervaring 'n verhoging in welsyn kan reflekteer (vgl. Ellison et al., 1989:118). Terselfdertyd is dit nie noodwendig dat 'godsdienstigheid', as sodanig, geestesgesondheid waarborg nie. Wayne Oates (1970:16) waarsku juis teen hierdie naïewe opvatting:

\footnotetext{
The term 'religious' is very ambiguous and like the word 'love', it covers a multitude of sins. ... It can refer to a very positive, 'health-giving' doctrine by which men not only survive but live and do well. When religion becomes reified - that is, made a thing of as separate and apart from the total expression of the whole life of the person - it becomes an external 'it', a thing apart. When this happens, the 'it' religion becomes either a segregated, autonomous system in an airtight compartment separated from the rest of life, or it becomes a disturbing factor in the total functioning of the person. In either instance, it is sick. In these laller instances, a person's 'religion' becomes 'bad news' instead of good news. Such religion is sick and not well. When we use the word 'religion', then, we are not necessarily saying that something is good.
}

Alhoewel die Christelike boodskap dus nie geestesgesondheid waarborg nie en soms tot so 'n mate verdraai kan word dat dit mense bind in plaas van vry maak, is die evangelie in sy wese leweskeppend (vgl. De Jongh van Arkel, 1990:1). Die meerderheid navorsing het, ten spyte van al die voorwaardes wat nou gestel is, nogtans getoon dat godsdienstigheid of een van die dimensies van godsdienstigheid 'n positiewe impak op die geestesgesondheid of psigologiese welsyn van volwassenes het (Ferraro \& Albrecht-Jensen, 1991:194). Verskeie pogings is reeds aangewend om die twee sake (geloofsvolwassenheid en geestesgesondheid) nader aan mekaar te bring en die interafhanklikheid aan te dui (vgl. Overduin, 1967; Cramer, 1959; Cosgrove \& Mallory, 1977; Ellens, 1982; Clinebell, 1965, 1979; Simundson, 1989). Twee van die faktore wat deurlopend met positiewe geestesgesondheid geassosieer word, is betekenis en doel in die lewe en betrokkenheid by 'n effektiewe sosiale ondersteuningsisteem (Bufford \& Buckler, 1987:26). Albei hierdie faktore hou direk verband met die Christelike kerk en haar boodskap.

Definisies van geestesgesondheid is gewoonlik omvattend:

Mental health is a condition of well-being in relation to self and others characterized by such qualities as (a) positive self-acceptance, (b) accurate perception of others and the world, (c) stability and appropriateness in mood, (d) balance and purposiveness in behavior, (e) dependable sense of identity and values, (f) adaptibility to one's environment, ( $g$ ) ability to engage in productive work and fulfilling love, and (h) commitment to a source of devotion 
beyond oneself. As such mental health is an active process, not merely the absence of illness (Aist, 1990:711).

Hierdie beskrywing van geestesgesondheid sal ook met verskeie aspekte van die Christelike boodskap versoen kan word en sou selfs tot 'n mate kan ooreenstem met beskrywings van geloofsvolwassenheid.

Die navorsing wat Idler (1987:228-229) gedoen het, is van belang vir die kerk se betrokkenheid by gesinsmoord, en daar behoort kennis geneem te word van haar bevindinge. Sy het aanduidings gevind dat vier meganismes in sowel private as in openbare godsdienstigheid 'n positiewe uitwerking op gesondheid het:

- Gesondheidsgedrag - godsdienstigheid verminder gedrag wat destruktief is vir gesondheid.

- Sosiale kohesie - godsdienstigheid aktiveer 'n sosiale netwerk wat help om te hanteer en te ondersteun.

- Kognitiewe koherensie - godsdienstigheid aktiveer 'n spesiale betekenissisteem wat sin geen aan die lewe.

* Interaktiewe teodisee - godsdienstigheid modifieer persepsies van ellende wat geassosieer word met fisiese lyding en gee sodoende dikwels hoop aan die indiwidu.

Die konklusie sou wel gemaak kan word dat, indien die evangelie van Christus geïnternaliseer sou word in 'n persoon se lewe, 'n situasie geskep is wat nie bevorderlik vir gesinsmoord is nie. Die kerklike bediening (kerugma, leiturgia, diakonia en koinonia) behoort 'n konteks van lewe en hoop te skep wat bevorderlik is vir geestesgesondheid en remmend inwerk ten opsigte van destruktiewe gedrag.

\subsection{Gemeentes as ekologieë van sorg}

Ook Ellison et al., (1989:117) se navorsing beweeg in dieselfde rigting wanneer hulle konkludeer dat sowel openbare as private godsdienstigheid, indiwiduele lewensbevrediging mag beïnvloed deur die negatiewe impak van stresvolle lewensomstandighede en gebeure te verlig. Terwyl hoë vlakke van toewyding ${ }^{2}$ en religieuse ervaring mense

2 Intensiteit van toewyding is gemeet deur navraag te docn oor die frekwensie van gebed en nabyheid aan God (Ellison et al., 1989:108). 
mag toerus met persoonlike bronne wat funksioneel is in die hantering van trauma, mag integrasie in religieuse samekomste instrumentele sosiale ondersteuning sowel as die versterking van gedeelde waardes en die nodige verklaring of interpretasie van lewensgebeure voorsien. Dit wil, met ander woorde, voorkom of die ondersteuningsgroepe wat in die godsdienstige groeperings bestaan, 'n positiewe uitwerking op die geestesgesondheid van mense het, aangesien dit hulle in tye van nood toegang tot emosionele, kognitiewe en materiële ondersteuning bied. Kerklike groepe kan 'n heilsame uitwerking op mense hê (vgl. die siening van Ferraro \& Albrecht-Jensen, 1991:200). Herbert Anderson (1989:126) wil eerder praat van 'n wisselwerking as 'n eenrigting-kousaliteit en trag om die verhouding meer sistemies as indiwidualisties te verstaan. Volgens hom is daar 'n wederkerige verband tussen die gesondheid van die gemeente en die geestesgesondheid van haar lede.

Toegepas op die probleem van gesinsmoorde is hier 'n paar sake wat met mekaar verbind kan word. Die meeste families betrokke by die navorsing oor gesinsmoord het nie die nodige ondersteuning van die sosiale strukture in hulle gemeenskap ontvang nie (Olivier et al., 1991a:212), onder andere, omdat hulle nie besonder betrokke was by die kerk en die gemeenskap nie (Olivier et al., 1991a:294). Dit wil voorkom of die algemene verval en disfunksie van gemeenskapsondersteuning en betrokkenheid as gevolg van die indiwidualisering van die gemeenskap 'n invloed op die gesinne gehad het (Olivier et al., 1991a:196). Terselfdertyd was daar besliste aanduidings dat die gesinne 'n beperkte betrokkenheid by vriende en ander mense gehad het (Olivier et al., 1991a:293). Die ekologie van sorg (Fowler, 1987:20) of die sorgende gemeenskap van liefde (Anderson, 1989:124) wat kenmerkend van die Christelike gemeente behoort te wees en in hierdie omstandighede die nodige ondersteunende hulp kon gebied het, het of nie gefunksioneer nie of is nie toegelaat om funksioneel te wees nie. In die lig van die feit dat daar 'n lae kerklike betrokkenheid by hierdie groep was, is daar ook die moontlikheid dat die sorgende konteks van die gemeente alleen funksioneel is vir die aktiewe lidmate.

Die bevinding dat godsdienstigheid bydra tot 'n gevoel van subjektiewe welsyn hou volgens Petersen en Roy (1985:59) verband met die verhoogde sosiale integrasie wat godsdienstige betrokkenheid gewoonlik meebring. Hulle vind dat die sosiale ondersteuningsfunksie van godsdienstige deelname meer bydra tot 'n persoon se vermoë om teenslae te hanteer as net godsdienstige geloof en oriëntasie. Die belang van die sosiale aspek van godsdiens word, met ander woorde, hier beklemtoon. Die gereelde basis van samekomste voed vriendskappe en sosiale bande. Terselfdertyd bring dit indiwidue in aanraking met ander wat moontlik deur dieselfde ervarings gegaan het. 
Terwyl 'n goed funksionerende Christelike kerk die ideale konteks vir die voorsiening van betekenis en doel in die lewe is en blootstelling aan 'n effektiewe sosiale ondersteuningsisteem bied (Bufford en Johnston, 1982:360), is hierdie sake juis aspekte wat direk met geestesgesondheid geassosieer word (Bufford \& Buckler, 1987:26). Weer eens moet daar versigtig konklusies getrek word want Petersen en Roy (1985:58) het nie gevind dat die sosiale aspekte van godsdiens (deelname of kerkbywoning) ' $n$ belangrike bron vir betekenis en doel is nie al het dit 'n negatiewe effek op angs.

Dit wil dus skyn of betrokkenheid by die kerk nie noodwendig beteken dat die lewe vir mense betekenis en doel het nie. 'n Sorgende ekologie is nie genoegsaam om mense by te staan in allerlei sake wat hulle die gevoel gee dat die lewe nie meer sin het nie. Die belangrike element lê in die ondersteunende aspek van die koinonia.

Ten opsigte van die sosiale aspek van die koinonia is dit ook belangrik om die kwalitatiewe verskil tussen 'n sosiale netwerk en 'n sosiale ondersteuningsisteem in ag te neem. Terwyl 'n netwerk gedefinieer word in terme van 'n fokuspersoon en verbindings met mense wat vir jou belangrik is, bestaan 'n sosiale ondersteuningsisteem uit mense wat as buffers teen psigososiale stres kan dien en/of help om by stresvolle situasies aan te pas. Die sosiale netwerk is nie noodwendig 'n hulp nie want daar mag juis mense daarin teenwoordig wees wat jou stres verhoog (Walfish \& Weinberg, 1979:124).

Ondersteuning gee uitvoering aan die opdrag van Galasiërs 6 en Romeine 15 om mekaar se laste en swakhede te help dra. Ondersteuning kan dus teologies verantwoord word. Verder kan dit ook psigologies verantwoord word: enigeen wat deur situasies gaan wat of nie verander kan word nie, of baie stadig verander en daarom aanleiding kan gee tot gevoelens van hulpeloosheid, het ondersteuning nodig (Pearson, 1982:83). Ondersteuning bied vir mense in nood bemoediging, troos en gerusstelling.

Drie verskillende raamwerke kan gebruik word om konkreet gestalte te gee aan die ondersteunig wat in die onderlinge sorg van gemeentes behoort te funksioneer.

Die eerste raamwerk is dié van Gerald Caplan (1974:6). Volgens hom bevat sowel langas korttermynondersteuning gewoonlik drie elemente:

- Dit help die persoon in nood om sy/haar geestelike en psigologiese bronne te mobiliseer en sodoende sy/haar laste te bemeester. 
- Dit deel die take van die ander deur dit te help dra en hanteer.

- Dit voorsien die persoon in nood van ekstra kos, geld, materiaal, middele (tools) en vaardighede sowel as kognitiewe en geestelike leiding om sy/haar hantering van die situasie te vergemaklik.

Die tweede raamwerk deel die ondersteuning in drie kategorieë, wat elk weer sy eie onderafdelings het (Pearson, 1982).

- Emosioneelgerigte ondersteuning wat tot uiting kom in

- Liefde: sorg (caring); emosionele 'deel'; toegeneentheid; warmte.

- Intimiteit: fisiese nabyheid en kontak; seksuele bevrediging.

- Kameraadskap: die deel van aktiwiteite; gevoel van behoort aan, toebehoort; gesamentlikheid.

- Aanvaarding: respek; empatie; begrip; vertroue; 'n reseptiewe, ontvanklike oor.

- Voorbeeld: modellering van hoe jy is en hoe om te lewe.

- Hulp: materiële bystand; die doen van dinge vir ander.

* Kognitiefgerigte ondersteuning geskied gewoonlik meer van 'n afstand af terwyl die impak van die aksie meer op die kognitiewe vlak gerig is. Hierdie tipe ondersteuning behels onder andere:

- Aanmoediging: die uitdrukking van vertroue in die ander; bevestiging van die ander se vermoëns; versterking van die ander se vaardighede.

- Vertroosting (comfort): gerusstelling; vergiffenis; iemand wees op wie gesteun kan word.

- Leiding/begeleiding: raadgewing; koersaanwysing; geestelike bystand.

- Kennis: intellektuele stimulasie; voorsiening van kennis van die saak, inligting of instruksies.

- Eerlikheid: eerlike terugvoer; 'n ware klankbord; egtheid vir die bied van 'n perspektief op jouself.

* Geïdealiseerde ondersteuning sluit die geidealiseerde idees van die wisselwerking tussen mense in. Vir hierdie soort ondersteuning is daar'n outeur (bewerker of originator) nodig (wat, byvoorbeeld, uitdrukking gee aan naasteliefde) en ook 'n ontvanger van die liefde, bewondering en aandag. Geïdealiseerde ondersteuning bestaan uit: 
- Bewondering: prys; lof; aandag; belangstelling.

- Bevrediging: vreugde wat spruit uit die geleentheid om iets by te dra tot iemand anders se lewe.

Die derde raamwerk het ondersteunende gedrag in vyf dimensies geplaas (Walfish \& Weinberg 1979:124):

- Emosionele ondersteuning

- Instrumentele ondersteuning

- Sosiale aktiwiteit/rekreasie

- Diens ondersteuning (om iemand fisies te help met 'n taak)

- Voorsiening van advies en nodige inligting

Uit bogenoemde is dit duidelik dat navorsing oor die ondersteunende funksie van die kerk genuanseerd moet wees. In die toekomstige navorsing oor gesinsmoord sal dit ook nie genoeg wees om te probeer bepaal of iemand aan 'n kerk behoort het of nie en selfs of die persoon (en gesin) besonder betrokke was by die gemeente nie. Dit is nie noodwendig dat daardie persoon (gesin) werklik opgeneem is in die sorgende ondersteuning van die gemeente nie. Waar daar funksionele ondersteuning in 'n gemeente gebied word, kan daar verwag word dat die mense wat daaraan blootgestel is nie oorweldig sal word deur 'n gevoel van hulpeloosheid (soos by die gesinsmoord) wanneer verskeie moeilike sake gehanteer moet word nie.

\subsection{Hoop vir hopeloses}

Terwyl hoop 'n sentrale tema in die Christelike evangelie is, is die gevoel van hopeloosheid 'n dominante verskynsel by die gesinsmoordenaar (Olivier $\boldsymbol{e t}$ al., 1991a:282). Hopeloosheid is ook gekoppel aan hulpeloosheid: die oortuiging dat daar geen vermoëns in jouself meer is om probleme op te los nie. Alhoewel gevoelens van hopeloosheid, hulpeloosheid en depressie (wat baie prominent was by die gesinsmoordenaars) mekaar voed, is daar gevind dat hopeloosheid 'n meer betroubare indikasie van selfmoord is as depressie (Kovaks et al, 1975:102).

Daar is altyd die moontlikheid dat hoop in die hopelose situasie nie die mens aanspoor om die probleme te verwerk en op te los nie maar juis om dit te vermy. Overduin (1975:205) het met verwysing na die Elia-gebed van 1 Konings 19:4 ("Nou is dit genoeg Here! Neem my lewe"), gepraat van die hoop wat onsuiwer geword het. Volgens hom is hierdie tipe hoop meer ' $n$ verlange om van al die teleurstellings en negatiewe 
lewensomstandighede af weg te kom as om met Christus te wees. Die Christelike hoop wys nie net bo hierdie lewe uit nie maar gee ook uitdrukking aan 'n "qualitatiewe en existentiele eschatologie" (Overduin, 1975:9). Gerkin (1979:24) se teorie dat die moderne mens, wat op eie krag moet staatmaak en terselfdertyd die sekerheid van God se voorsienigheid verloor het, baie meer kwesbaar is omdat hy gekonfronteer word met sy eie beperkings en eindigheid, kan ook op die gesinsmoordsituasie toegepas word.

Die kerk sal die boodskap van die koms van Christus en sy Gees so moet verkondig dat dit eksistensiële waarde het vir mense wat so vasgevang word in hul skynbaar onoplosbare probleme dat hulle sonder hoop is. Binne 'n situasie waar die apokalipsis domineer, moet daar ook ruimte gemaak word vir 'n eksistensiële eskatologie. Indien dit waar is dat eskatologie alleenlik bestaan as ekstrapolasie van ervarings wat ons in ons eie wêreld en geskiedenis met God opdoen (Berkhof, 1973:16), dat die wete van die getrouheid van God gegrond is in my kennis van God se betrokkenheid in die verlede en die hede (Berkhof, 1968:160) en dat die geloof in die aktuele verhouding tot God en sy reële teenwoordigheid die basis van alle heilsverwagting is (Vriezen, 1966:467), plaas dit 'n moeilike taak op die kerk om die God wat in die hede vir die hede aan die werk is ook ' $n$ werklikheid vir mense te maak. Die verlange na die dood mag nie versterk word deur 'n verwagting dat ek eers na die dood met God sal wees nie. Die sekerheid van die teenwoordigheid van God mag nooit verdring word deur 'n verlange na die hemel nie.

Die inhoud en die kwaliteit van geloof funksioneer op die vlak van primêre voorkoming van geestesgesondheid en skep 'n situasie wat mense die vermoëns gee om krisisse en teenslae te verwerk. Alle insidente waarby mense betrokke is, word vanuit 'n bepaalde (persoonlike) betekenisraamwerk verwerk (De Jongh van Arkel, 1988). Indien die spiritualiteit 'n semantiese raamwerk bied wat die getrouheid en teenwoordigheid van God reflekteer, is die moontlikheid groter dat 'n krisis nie sal ontstaan wat in 'n gesinsmoord sal eindig nie.

\section{$2.5 \quad$ Kategese en pastoraat}

'n Laaste aspek wat hier aandag kry, is die verantwoordelikheid wat die finale RGNverslag op die kerk en predikante plaas om betrokke te wees by voorkomende aksies (soos vir die huwelik) wat veral programme vir lewensvaardighede (life-skills programmes) insluit (Olivier et al., 1991a:305, 307-310). Hierdie programme is gemik op vaar- 
dighede soos effektiewe kommunikasiestyle, probleem- en konflikoplossing, selfgeldingskoling (assertiveness training) - maar met die klem op die feit dat die ontwikkeling van slegs een van die persone in 'n verhouding tot ernstige probleme kan lei, 'n sorgende houding teenoor ander en die lewe in die algemeen, hantering van stres, vryetydhantering, huweliksverryking, huweliksvoorbereiding, voorbereiding vir ouerskap, hulp aan ouers om kinders (saam met skole) te leer hoe om emosionele probleme te hanteer.

Indien hierdie aanbevelings ernstig geneem word, sou dit beteken dat die kerk erken dat sy naas die geloofsopvoeding en hulp ook ' $n$ taak het ten opsigte van lewensopvoeding en lewenshulp. Tot ' $n$ mate word dit reeds in kategese en pastoraat gedoen. Heel waarskynlik mag dit nodig wees om bepaalde aspekte spesifiek uit te brei en aktief uit te bou. Om maar enkeles te noem:

- Lewensopvoeding kan lei tot 'n groter toegespitste huweliksvoorbereiding, huweliksverryking asook huwelikspastoraat.

* Die doopkategese sal nie net die doop as onderwerp moet hê nie maar die saak van ouerskap en die implikasie daarvan sal in veel meer as net een gesprek gehanteer moet word.

\section{TEN SLOTTE}

Indien die implikasie van 'n verskynsel soos gesinsmoord na die kerk deurgetrek word, blyk dit dat dit verreikende gevolge vir die kerk het. Positief toon dit weer die uiters belangrike (en sentrale) rol wat die kerk in die gemeenskap speel en ook die groot verwagting van die kerk om funksioneel by mense se lewens betrokke te wees. Negatief toon dit ook verskeie leemtes aan waaraan die kerk sou moet aandag gee indien die kerk bereid sou wees om na haarself te kyk in die lig van hierdie gebeure. Die kerk se rol is veel wyer as dit wat hier aangedui is, en baie ander sake, wat direk verband hou met gesinsmoorde, sou aangedui kon word. Dit is egter belangrik om die gesprek oor die rol van die kerk in die samelewing en die rol van die kerk ten opsigte van geestesgesondheid aan die gang te kry.

\section{BIBLJOGRAFIE}

AIST, C.S. 1990. Mental Healih and Illness. (In Hunter, R.J. Dictionary of Pastoral Care and Counscling. Nashville : Abingdon. p. 711-714.) 
ANDERSON, H. 1989. The Congregation: Health Center or Healing Community. Word \& World, 11:123-131.

BERKHOF, H. 1968. Gegronde verwagting: schets van een Christelijke toekomsleer. Nijkerk Callenbach.

BERKHOF, H. 1973. Christelijk geloof: een inleiding tot de geloofsleer. Nijkerk : Callenbach.

BROWNING, D.S. 1983. Religious Ethics and Pastoral Care. Philadephia : Fortress.

BUFFORD, R.K. \& BUCKLER, R.E. 1987. Counseling in the Church: A Proposed Strategy for Ministering to Mental Health Needs in the Church. Joumal of Psychology and Christianity, 6(2):21-29.

BUFFORD, R.K. \& JOHNSTON, T.B. 1982. The Church and Community Mental Health: Unrealized Potential. Joumal of Psychology and Theology, 10:355-362.

CAPLAN, G. 1974. Support Systems and Community Health. New York: Basic Books.

CLINEBELL, H.J. 1965. Mental Health through Christian Community: The Local Church's Ministry of Growth and Healing. New York : Abingdon.

CLINEBELL, H. 1979. Growth Counseling: Hope Centered Methods of Actualizing Human Wholeness. Nashville : Abingdon.

COSGROVE, M.P. \& MALLORY, J.D. 1977. Mental Health: A Christian Approach. Grand Rapids, Mich. : Zondervan.

CRAMER, R.L. 1959. The Psychology of Jesus and Mental Health. Grand Rapids, Mich. : Zondervan.

CRAWFORD, M.E., HANDAL, P.J. \& WIENER, R.L. 1989. The Relationship between Religion and Mental Health/Distress. Review of Religious Research, 3116-22.

DE JONGH VAN ARKEL, J.T. 1985. Gesinsmoord: 'n pastoraal-teologiese perspektief. SuidAfrikaanse Tydskrif vir Sirofreg en Kriminologie, 9:140-148.

DE JONGH VAN ARKEL, J.T. 1988. Spiritualiteit as semantiese struktuurkern: 'n pastorale perspektief. Praktiese Teologie in Suid-Afrika, 4(2): 18-30.

DE JONGH VAN ARKEL, J.T. 1990. Making Religion Work in the Family. Ongepubliseerde referaat gelewer by die konferensie van die Suid-Afikaanse Nasionale Raad vir Geestesgesondheid. Johannesburg.

ELLENS, J.H. 1982. God's Grace and Human Health. Nashville : Abingdon.

ELLISON, C.G., GAY, D.A. \& GLASS, T.A. 1989. Does Religious Commitment Contribute to Individual Life Satisfaction? Social Forces, 68:100-123.

FERRARO, K.F. \& ALBRECHT-JENSEN, C.M. 1991. Does Religion Influence Adult Health? Joumal for the Scientific Study of Religion, 30:193-202.

FOWLER, J.W. 1987. Faith Development and Pastoral Care. Philadephia : Fortress

GERKIN, C.V. 1979. Crisis Experience in Modern Life: Theory and Theology in Pastoral Care. Nashville : Abingdon.

IDLER, E.L. 1987. Religious Involvement and the Life of the Elderly: Some Hypotheses and an Initial Test. Social Fonces, 66:226-238.

KOVAKS, M., BECK, A.T. \& WEISSMAN, A. 1975. Hopelessness: An Indicator of Suicidal Risk. Suicide, 5:98-103.

KUITERT, H.M. 1981. Pluraliteit van moraal in de Christelijke gemeente. (In Vlijm, J.M., red. Geloofsmanieren: studies oyer pluraliteit in de kerk. Kampen : Kok. p. 237-279.)

LARSON, D.B., HOHMANN, A.A., KESSLER, L.G., MEADOR, K.G., BOYD, J.H. \& MCSHERRY, E. 1988. The Couch and the Cloth: The Need for Linkage. Hospital and Community Psychiatry, 39:1064-1069.

OATES, W.E. 1970. When Religion Gets Sick. Philadelphia : Westminster. 
OLIVIER, L., HAASBROEK, C.P., BEYERS, D., DE JONGH VAN ARKEL, J.T., MARCHETTI, M.C., ROOS, J.L., SCHURINK, E.M, SCHURINK, W.J. \& VISSER, M.J. 1991a. The Phenomenon of Family Murder in South Africa: An Exploratory Study. Pretoria : Human Sciences Research Council.

OLIVIER, L., HAASBROEK, C.P., BEYERS, D., DE JONGH VAN ARKEL, J.T., MARCHETTI, M.C., ROOS, J.L., SCHURINK, E.M, SCHURINK, W.J. \& VISSER, M.J. 1991b. The Phenomenon of Family Murder in South Africa: An Exploratory Study. Appendix: case studies. Pretoria : Human Sciences Research Council.

OLIVIER, L., HAASBROEK, C.P., BEYERS, D., DE JONGH VAN ARKEL, J.T., MARCHETTI, M.C., ROOS, J.L., SCHURINK, E.M, SCHURINK, W.J. \& VISSER, M.J. 1991c. The Phenomenon of Family Murder in South Africa: An Exploratory Study: Summary. Pretoria : Human Sciences Research Council.

OVERDUIN, J. 1967. Worden als een man: over de geestelijke volwassenheid. Wageningen : N.V. Gebr. Zomer \& Keunings.

OVERDUIN, J. 1975. Het onaantasbare: over de Christelijke hoop. 3de hersiene druk. Kampen : Kok.

PEARSON, R.E. 1982. Support: Exploring of a Basic Dimension of Informal Help and Counseling. The Personnel and Guidance Joumal, 61:83-87.

PETERSEN, L.R. \& ROY, A. 1985. Religiosity, Anxiety, and Meaning and Purpose: Religion's Consequences for Psychological Well-Being. Review of Religious Research, 27:49-62.

SANUA, V.D. 1977. Religion, Mental Health and Personality: A Review of Empirical Studies. (In Malony, H.N., ed. Current Perspectives in the Psychology of Religion. Grand Rapids, Mich.: Eerdmans. p. 173-190.)

SIMUNDSON, D.J. 1989. Mental Health in the Bible. Word \& World, 9:140-146.

TJELTVEIT, A.C. 1989. Psychotherapcutic Triumphalism and Freedom from Mental Illness: Diverse Concepts of Mental Health. Word \& World, 9:132-139.

VRIEZEN, Th.C. 1966. Hoofdlijnen der teologie van het Oude Testament. 3de hersiene druk. Wageningen : H. Veenman en Zonen N.V.

WINETT, R.A., MAJORS, J.S. \& STEWART, G. 1979. Mental Health Treatment and Referral Practices of Clergy and Physician Carcgivers. Joumal of Community Psychology, 7:318-323.

WALFISH, S. \& WEINBERG, R.B. 1979. Social Support Systems for Crisis Intervention. Crisis Intervention, 10:122-142. 
